\title{
Mengoptimalkan Penggunaan Model Inquiri Learning Upaya Meningkatkan Aktivitas Dan Hasil Belajar Pendidikan Agama Hindu Peserta Didik Kelas IV Semester Satu Tahun Pelajaran 2019/2020 Di SD Negeri 34 Cakranegara
}

\author{
Desak Ketut Warnita \\ Guru Kelas IV SD Negeri 34 Cakranegara
}

\begin{abstract}
Abstrak. Penelitian ini bertujuan untuk mengetahui efektifitas penerapan pendekatan Saintifik model Pembelajaran Inquiri dalam upaya meningkatkan Aktivitas dan hasil belajar Pendidikan Agama Hindu Peserta didik Kelas IV SD Negeri 34 Cakranegara. Manfaat penelitian ini adalah mendorong peserta didik untuk mengembangkan ketrampilan belajar dalam kelompok (kognitif) dan bersosiolisasi dengan teman dalam proses pembelajaran di kelas senyatanya. Dan bagi guru meningkatkan pengembangan pendekatan dan model pembelajaran dengan penerapan saintifik Model Pembelajaran Inquiri dalam pembelajaran kerja kelompok (kooperatif). Penelitian ini dilaksanakan dua siklus, masing-masing siklus kegiatannya adalah; perencanaan, pelaksanaan, observasi dan refleksi. Hasil akhir tindakan pada siklus II menunjukkan bahwa hasil observasi guru pada pertemuan kedua memperoleh skor rata-rata $(4,43)$ dan hasil observasi Peserta didik pertemuan kedua mencapai skor rata-rata $(4,63)$. Sedangkan hasil belajar Peserta didik mencapai nilai rata-rata $(80,89)$, artinya indikator keberhasilan $(\geq 4,0)$ dan hasil belajar $(\geq 75,00)$ telah terlampaui. Karena indikator keberhasilan telah terbukti penelitian dinyatakan berhasil dan dihentikan pada siklus II.
\end{abstract}

Kata Kunci : Aktivitas dan hasil Belajar-Pendekatan Saintifik Model Pembelajaran Inquiri.

\section{PENDAHULUAN}

\section{Latar Belakang}

Untuk bisa menciptakan kegiatan belajar mengajar yang melibatkan peran aktif siswa, ada beberapa cara yang bisa dilakukan seorang guru, salah satunya dengan menerapkan macam - macam model pembelajaran. Beberapa model pembelajaran yang melibatkan peran aktif siswa adalah model pembelajaran Inkuiri. Dengan model pembelajaran ini siswa akan lebih ditekankan untuk berperan aktif dan menemukan sesuatu yang baru untuk dipelajari.

Proses pembelajaran di SD Negeri 34 Cakranegara khususnya pada mata pelajaran Pendidikan Agama Hindu yang berlaku selama ini masih cenderung mengarah pada guru yang aktif menjelaskan materi pelajaran dengan berapi-api tanpa memperdulikan kondisi peserta didiknya.Proses pembelajaran semacam ini telah melahirkan peserta didik yang pasif, kurang kreatif, kurang termotivasi dalam mengingat pelajaran Pendidikan Agama Hindu sehingga prosentase keberhasilan pada peserta didik sangat memprihatinkan dan berdampak pada rendahnya tingkat kepercayaan peserta didik terhadap guru Pendidikan Agama Hindu dalam proses pembelajaran di kelas senyatanya.

Kondisi nyata yang terjadi pada peserta didik kelas IV SD Negeri 34 Cakranegara adalah sebagai berikut: 1) peserta didik di kelas IV ini merupakan penyebaran dari sekolah-sekolah yang kualitasnya rendah, 2) peserta didik yang pada saat proses pembelajaran kurang termotivasi dan cenderung bermain-main, saling lempar buku, keluar masuk kelas tanpa izin, 3) peserta didik yang aktivitas belajarnya rendah dan pada saat diadakan ulangan harian memperoleh nilai rata-rata di bawah KKM. Kondisi sebagaimana tersebut diatas dialami pula pada proses pembelajaran mata pelajaran Pendidikan Agama Hindu. Selama proses pembelajaran peserta didik cenderung tidak peduli terhadap apa yang disampaikan oleh guru mata pelajaran. Ketika guru meminta kepada peserta didik untuk bertanya terhadap materi pelajaran yang disajikan, jika ternyata belum faham, belum mengerti, atau tidak tahu sama sekali semuanya diam, ketika peserta 
didik di berikan tugas secara berkelompok hanya beberapa orang peserta didik saja yang aktif. Ketika masing-masing kelompok disuruh maju untuk mempresentasikan hasil kerja kelompoknya cenderung tidak bersedia bahkan masing-masing anggota kelompok saling tunjuk dan tidak ada hasilnya.

Faktor penyebab terjadinya situasi kelas yang sangat kurang kondusif dalam proses pembelajaran tersebut adalah berasal dari guru itu sendiri maupun berasal dari peserta didik. Selama ini guru Pendidikan Agama Hindu mengajar cenderung mendominasi dengan gaya ceramah yang berapi-api tanpa memperdulikan kondisi peserta didik. Guru Pendidikan Agama Hindu sekaligus sebagai peneliti sebenarnya sudah menerapkan pendekatan saintifik sebagaimana yang tertera pada Permen 81 A Tahun 2013 tentang kurikulum 2013, tetapi masih belum optimal dan belum sesuai dengan harapan. Sementara penyebab dari peserta adalah rendahnya kompetensi yang dimiliki serta kurang gairah dalam mengikuti pelajaran Pendidikan Agama Hindu. Apapun yang ditugaskan oleh guru, peserta didik nampak cuek dan tidak peduli akan akibat yang akan terjadi pada dirinya.

Banyak solusi yang bisa dilakukan oleh peneliti, tetapi yang dianggap mampu meningkatkan aktivitas dan hasil belajar peserta didik kelas IV mata pelajaran Pendidikan Agama Hindu yaitu dengan mengoptimalkan pendekatan "saintifik" dengan menggunakan Model pembelajaran Inquiri. Pendekatan saintifik ini memiliki keunggulan bila di bandingkan dengan pendekatan yang lain karena proses pembelajaran terdiri atas lima pengalaman belajar pokok yaitu; a) mengamati, b) menanya, c) mengumpulkan informasi, d) mengasosiasi, dan e) mengkomunikasikan. Dalam pengembangan kegiatan pembelajar dengan pendekatan saintifik ini dirancang sebagai berikut; 1) kegiatan pembelajaran disusun untuk dapat melaksanakan proses pembelajaran secara professional, 2) kegiatan pembelajaran memuat rangkaian kegiatan manajerial yang dilakukan guru agar peserta didik dapat melakukan kegiatan seperti di silabus, 3) kegiatan pembelajaran untuk setiap pertemuan merupakan scenario/langkah- langkah guru agar peserta didik aktif belajar. Kegiatan ini diorganisasikan menjadi kegiatan: pendahuluan, inti dan penutup.

Untuk membuktikan bahwa pendekatan saintifik model pembelajaran Inquiri dengan model diskusi dapat meningkatkan aktivitas dan hasil belajar peserta didik kelas IV Semester Satu tahun pelajaran 2019/2020 maka dipandang perlu untuk mengadakan penelitian tindakan kelas (PTK) dengan judul "Mengoptimalkan Penggunaan Model Inquiri Learning Upaya Meningkatkan Aktivitas Dan Hasil Belajar Pendidikan Agama Hindu Peserta Didik Kelas IV Semester Satu Tahun Pelajaran 2019/2020 Di Sd Negeri 34 Cakranegara".

\section{Rumusan Masalah}

"Apakah dengan mengoptimalkan penerapan model Pembelajaran Inquiri dapat meningkatkan aktivitas dan hasil belajar Pendidikan Agama Hindu peserta didik kelas IV Semester Satu tahun pelajaran 2019/2020 di SD Negeri 34 Cakranegara?"

\section{Tujuan Penelitian}

"untuk mengetahui efektifitas penerapan model Pembelajaran Inquiri dalam upaya peningkatan aktivitas dan hasil belajar Pendidikan Agama Hindu peserta didik kelas IV Semester Satu tahun pelajaran 2019/2020 di SD Negeri 34 Cakranegara."

\section{Manfaat Penelitian \\ * Bagi Peserta Didik}

1. Mendorong peserta didik untuk mengembangkan ketrampilan belajar dalam kelompok (kognitif) dan bersosiolisasi dengan teman dalam proses pembelajaran di kelas senyatanya.

2. Aktivitas belajar Pendidikan Agama Hindu bagi peserta didik dalam upaya pemahaman secara mandiri (eksplorasi) terhadap mata pelajaran Pendidikan Agama Hindu sehingga hasil belajar dapat ditingkatkan.

\section{* Bagi Guru Pendidikan Agama Hindu}

1. Meningkatkan pengembangan pendekatan dan model pembelajaran dengan penerapan model Pembelajaran Inquiri dalam pembelajaran kerja kelompok (kooperatif). 
2. Menumbuhkan aspirasi secara ilmiah dalam menjalankan profesi keguruan terutama dalam pengembangan keprofesian berkelanjutan (PKB) bagi guru Pendidikan Agama Hindu.

\section{KAJIAN PUSTAKA \\ Kerangka Teori \\ Aktivitas Belajar}

Aktivitas belajar adalah aktivitas yang bersifat fisik maupun mental. Dalam proses belajar kedua aktivitas itu harus saling berkaitan. Lebih lanjut lagi piaget menerangkan (dalam Sardiman, 2011:100) bahwa jika seorang anak berfikir tanpa berbuat sesuatu, berarti anak itu tidak berfikir.

Nanang Hanafiah dan Cucu Suhana (2010:24) menjelaskan bahwa aktivitas belajar dapat memberikan nilai tambah (added value) bagi peserta didik, berupa halhal berikut ini:

1. Peserta didik memiliki kesadaran (awareness) untuk belajar sebagai wujud adanya aktifitas internal untuk belajar sejati.

2. Peserta didik mencari pengalaman dan langsung mengalami sendiri, yang dapat memberikan dampak terhadap pembentukan pribadi yang integral.

3. Peserta didik belajar dengan menurut minat dan kemampuannya.

4. Menumbuh kembangkan sikap disiplin dan suasana belajar yang demokratis di kalangan peserta didik.

5. Pembelajaran dilaksanakan secara konkret sehingga dapat menumbuh kembangkan pemahaman dan berfikir kritis serta menghindarkan terjadinya verbalisme.

6. Menumbuh kembangkan sikap kooperatif dikalangan peserta didik sehingga sekolah menjadi hidup, sejalan dan serasi dengan kehidupan di masyarakat di sekitarnya.

alam penelitian ini yang dimaksud dengan aktifitas belajar adalah kegiatan peserta didik mengingat, memecahkan masalah, menganalisis faktor-faktor, melihat hubungan-hubungan, dan membuat keputusan terhadap masalah yang diberikan oleh guru kelas IV di SD Negeri 34 Cakranegara

\section{Hasil belajar}

Mukhtar (2003:54) mengatakan bahwa pengertian hasil belajar tidak dapat dipisahkan dan apa yang terjadi dalam aktifitas pembelajaran baik di kelas maupun diluar kelas. Apa yang dialami oleh peserta didik dalam proses pengembangan kemampuannya merupakan apa yang diperoleh dalam belajar dan pengalaman tersebut pada akhirnya dipengaruhi oleh beberapa faktor diantaranya keadaan kognitif, afektif dan psikomotornya pada waktu belajar. Kualitas pengajaran yang diterimanya dan cara pengelolaan proses interaksi yang dilakukan oleh guru. Masalah evaluasi hasil belajar meliputi alat ukur yang digunakan, cara menggunakan, cara penilaian dan evaluasinya (Harus Rasid dan Mansur, 2008:9). Evaluasi hasil belajar yang berhubungan dengan tugas guru rutin dilakukan evaluasi hasil, yang juga dijadikan umpan balik, evaluasi hasil bertujuan menilai apakah hasil belajar dicapai sesuai dengan tujuan (Lukmanul Hakim, 2008:165).

Pakar pendidikan lain mendefinisikan bahwa yang dimaksud hasil belajar adalah perubahan perilaku secara keseluruhan bukan salah satu aspek potensi kemanusiaan saja (Supriyono, 2009:19). Berbeda dengan pendapatnya Bloom (Dalam Sumiati danAska, 2008). Hasil belajar mencakup kemampuan kognitif, afektif, dan psikomotorik. Jadi pendapat ini mengisyaratkan bahwa haasil belajar peserta didik harus diukur dengan tes tertulis, tes sikap, dan kemampuan skil secara nyata selama proses pembelajaran di kelas senyatanya. Dalam penelitian ini yang dimaksud dengan hasil belajar adalah tes ulangan harian yang dilaksanakan secara tertulis pada akhir pembelajaran dan nilai hasil diskusi kelompok yang dinilai secara perorangan.

\section{Model Pembelajaran Inquiri}

Istilah "inkuiri" berasal dari bahasa Inggris, yaitu inquiry yang berarti pertanyaan atau penyelidikan. Pembelajaran inkuiri adalah pembelajaran yang melibatkan seluruh kemampuan peserta didik secara maksimal untuk mencari dan menyelidiki secara sistematis, kritis, logis, dan analitis, sehingga peserta didik dapat merumuskan sendiri penemuannya dengan penuh percaya diri. 
Model pembelajaran ini dikembangkan oleh seorang tokoh yang bernama Suchman. Suchman meyakini bahwa anak-anak merupakan individu yang penuh rasa ingin tahu akan segala sesuatu.

\section{Prinsip-prinsip Model Pembelajaran Inkuiri}

1. Berorientasi pada Pengalaman Intelektual Tujuan utama dari strategi pembelajaran inkuiri adalah pengembangan kemampuan berpikir. Dengan demikian, strategi pembelajaran ini selain berorientasi kepada hasil belajar, juga berorientasi pada proses belajar. Oleh karena itu, kriteria keberhasilan dari proses pembelajaran dengan menggunakan strategi inkuiri bukan ditentukan oleh sejauhmana peserta didik mampu menguasai materi pelajaran, tetapi sejauhmana peserta didik beraktifitas mencari dan menemukan sesuatu.

2. Prinsip interaksi

Proses pembelajaran pada dasarnya adalah proses interaksi, baik interaksi antara peserta didik maupun interaksi peserta didik dengan guru, bahkan interaksi antara peserta didik dengan lingkungan sekitarnya. Pendidik atau guru perlu mengarahkan agar peserta didik bisa mengembangkan kemampuan berpikirnya melalui interaksi mereka.

3. Prinsip bertanya

Tugas utama guru atau pendidik dalam menerapkan pembelajaran inkuiri adalah menjadi penanya yang baik bagi peserta didik. Artinya, bagaimana upaya yang harus dilakukan guru agar peserta didik menjadi kritis, kemudian melontarkan pertanyaanpertanyaan tajam. Berbagai jenis dan teknik bertanya perlu dikuasai oleh setiap guru, apakah itu bertanya hanya sekedar untuk meminta perhatian peserta didik, bertanya untuk melacak, bertanya untuk mengembangkan kemampuan, atau bertanya untuk menguji.

4. Prinsip belajar untuk Berpikir

Belajar bukan hanya mengingat sejumlah fakta, tetapi belajar adalah proses berpikir (learning how to think), yakni proses mengembangkan potensi seluruh otak, baik otak kiri maupun otak kanan, baik otak reptile, otak limbic, maupun otak neokorteks.

5. Prinsip Keterbukaan
Belajar adalah suatu proses mencoba berbagai kemungkinan. Segala sesuatu mungkin saja terjadi. Oleh karena itu, anak perlu diberikan kebebasan untuk mencoba sesuai dengan perkembangan kemampuan logika maupun nalarnya. Tugas guru adalah menyediakan ruang untuk memberikan kesempatan kepada peserta didik mengembangkan hipotes, dan secara terbuka membuktikan kebenaran hipotesis yang diajukan.

\section{Macam-macam Model Pembelajaran Inkuiri}

Beberapa macam model pembelajaran inkuiri yang dikemukakan oleh para ahli diantaranya sebagai berikut.

\section{Guide Inquiry}

Pembelajaran inkuiri terbimbing, yaitu suatu model pembelajaran inkuiri yang dalam pelaksanaannya guru menyediakan bimbingan atau petunjuk cukup luas kepada peserta didik. Sebagian perencanaannya dibuat oleh guru, peserta didik tidak merumuskan problem atau masalah. Dalam pembelajaran inkuiri terbimbing, guru tidak melepas begitu saja kegiatan-kegiatan yang dilakukan oleh peserta didik. Inkuiri terbimbing biasanya digunakan terutama bagi peserta didik yang belum berpengalaman belajar dengan pendekatan inkuiri.

\section{Modified Inquiry}

Model pembelajaran inkuiri ini memiliki ciri guru hanya memberikan permasalahan tersebut melalui pengamatan, percobaan, atau prosedur penelitian untuk memperoleh jawaban. Di samping itu, guru merupakan narasumber yang tugasnya hanya memberikan bantuan yang diperlukan untuk menghindari kegagalan dalam memecahkan masalah. Jika perlu peserta didik tidak mengalami kegagalan dan mampu memecahkan masalahnya, guru hanya sebagai fasilitator saja.

\section{Free Inquiry}

Pada model ini peserta didik harus mengidentifikasikan dan merumuskan macam problem yang dipelajari dan dipecahkan. Pada model inkuiri ini guru memberikan masalah saja, sedangkan prosedur dan pemecahan masalah tergantung kepada peserta didik. Jadi, pembelajaran aktif akan terbentuk dalam 
model ini. Namun, model pembelajaran ini akan mengakibatkan peserta didik yang berada di bawah standar tidak mampu mengikuti pelajaran dengan baik.

\section{Inquiry Role Approach}

Pendekatan model pembelajaran inkuiri ini melibatkan peranan peserta didik dalam timtim yang masing-masing terdiri atas empat orang untuk memecahkan masalah yang diberikan. Masing-masing anggota memegang peranan yang berbeda, yaitu sebagai koordinator tim, penasihat teknis, pencatat data, dan evaluator proses.

\section{Invitation Into Inquiry}

Jenis model inkuiri ini melibatkan peserta didik dalam proses pemecahan masalah dengan cara-cara lain yang ditempuh para ilmuwan. Suatu invitasi memberikan problem atau masalah kepada peserta didik melalui pertanyaan yang telah direncanakan dengan hati-hati dan mendorong peserta didik untuk melakukan beberapa kegiatan sebagai berikut:

a) merancang eksperimen; b) merumuskan hipotesis; c) menentukan sebab akibat; d) menginterpretasikan data; e) membuat grafik; f) menentukan peranan dalam diskusi dan kesimpulan dalam merencanakan penelitian; g) mengenal bagaimana kesalahan eksperimental mungkin dapat dikurangi dan diperkecil.

\section{Pictorial Riddle}

Model ini merupakan model pembelajaran yang dapat mengembangkan motivasi dan minat peserta didik dalam diskusi kelompok kecil atau besar yang dapat digunakan untuk meningkatkan cara berpikir kritis dan kreatif para peserta didik. Biasanya, suatu materi berupa gambar di papan tulis, poster yang diproyeksikan dari suatu transparansi kemudian guru mengajukan pertanyaan yang berkaitan dengan materi itu.

7. Synestics Lesson

Pada jenis ini guru hendaknya memusatkan keterlibatan peserta didik untuk membuat berbagai macam bentuk kiasan supaya dapat membuka intelegensinya dan mengembangkan kreativitasnya. Hal ini dapat dilaksanakan karena kiasan dapat membantu peserta didik dalam berpikir untuk memandang suatu problem sehingga dapat menunjang timbulnya ide-ide kreatif.

\section{Value Clarification}

Pada model pembelajaran inkuiri jenis ini peserta didik lebih difokuskan pada pemberian kejelasan tentang suatu tata aturan atau nilai-nilai pada suatu proses pembelajaran. Model pembelajaran yang satu ini merupakan bagian dari model pembelajaran inkuiri yang mengarah pada internalisasi nilai-nilai yang telah menjadi sebuah budaya. Praktiknya adalah peserta didik diajak untuk mengenal nilai-nilai yang ada di sekitarnya lalu diarahkan untuk mencari maksud dari nilai tersebut dan berusaha untuk diterapkan.

\section{Peran Guru dalam Model Pembelajaran Inkuiri}

Peranan utama guru dalam menciptakan kondisi inkuiri adalah sebagai berikut :

1. Motivator, yang memberi rangsangan supaya siswa aktif dan gairah berpikir.

2. Fasilitator, yang menunjukkan jalan keluar jika ada hambatan dalam proses berpikir siswa.

3. Penanya, untuk menyadarkan siswa dari kekeliruan yang mereka perbuat dan memberi keyakinan pada diri sendiri.

4. Administrator, yang bertanggung jawab terhadap seluruh kegiatan di dalam kelas.

5. Pengarah, yang memimpin arus kegiatan berpikir siswa pada tujuan yang diharapkan.

6. Manajer, yang mengelola sumber belajar, waktu, dan organisasi kelas.

7. Rewarder, yang memberi penghargaan pada prestasi yang dicapai dalam rangka peningkatan semangat heuristik pada siswa.

\section{Kerangka Konseptual}

Kerangka konseptual ini menggambarkan hubungan antara variabel tindakan dan variabel harapan. Variabel tindakan yaitu mengoptimalkan penerapan pendekatan saintifik model pembelajaran inquiri, sedangkan variabel harapan adalah meningkatkan aktivitas dan hasil belajar.

\section{Hipotesis Tindakan}

"Jika penerapan Model Pembelajaran Inquiri dilaksanakan secara optimal maka aktivitas dan hasil belajar Pendidikan Agama Hindu peserta didik kelas IV Semester Satu 


\section{tahun pelajaran 2019/2020 dapat ditingkatkan". \\ PROSEDUR PENELITIAN}

\section{Setting Penelitian}

Penelitian tindakan kelas (PTK) ini akan dilaksanakan di kelas IV SD Negeri 34 Cakranegara Semester Satu tahun pelajaran 2019/2020, dengan jumlah peserta didik sebanyak 35 Orang

\section{Faktor yang Diteliti}

1. Faktor Guru: yaitu dengan mengganti cara guru membuat Rencana Pelaksanaan Pembelajaran (RPP) dan pelaksanaannya dalam pembelajaran di kelas senyatanya dengan menerapkan pendekatan saintifik model Pembelajaran Inquiri dalam upaya meningkatkan aktivitas dan hasil belajar Pendidikan Agama Hindu peserta didik Kelas IV SD Negeri 34 Cakranegara.

2. Faktor Peserta Didik: yaitu peningkatan aktivitas dan hasil belajar yang terlihat pada perilaku peserta didik selama diskusi kelompok, yang berdampak pada peningkatan aktivitas dan hasil belajar Pendidikan Agama Hindu peserta didik Kelas IV Semester Satu Tahun pelajaran 2019/2020 di SD Negeri 34 Cakranegara.

\section{Rencana Tindakan}

Penentuan tindakan yang dilakukan oleh guru, menurut Arikunto, $\mathrm{S}$. menggunakan alur karya tulis ilmiah sebagai berikut: kegiatan nyata di kelas IV yaitu melaksanakan proses pembelajaran dengan menerapkan model Pembelajaran Inquiri dalam upaya meningkatan aktivitas dan hasil belajar Pendidikan Agama Hindu peserta didik kelas IV SD Negeri 34 Cakranegara Semester Satu tahun pelajaran 2019/2020. Tindakan nyata yang dilakukan oleh guru selaku peneliti adalah dengan menggunakan siklus. Gambaran siklus dalam penelitian ini adalah sebagai berikut:

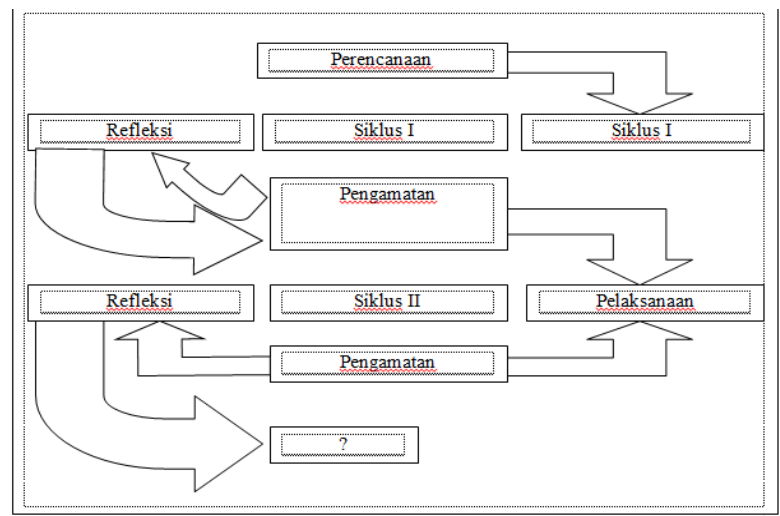

3.2 Alur Pelaksanaan Siklus

Setiap siklus selama penelitian ini berisi 4 (empat) tahapan yaitu: 1) Perencanaan (Planning), 2) Pelaksanaan (Action), 3) Observasi (Observation), dan 4) Refleksi (Reflection).

\section{Siklus Tindakan}

Masing-masing tahapan dalam setiap siklus berisikan kegiatan-kegiatan nyata yang akan dilaksanakan. Untuk mendapatkan tentang rincian kegiatan pada setiap tahapa dapat dijelaskan sebagai berikut:

\section{SIKLUS I}

\section{Tahap Perencanaan (Planning)}

1. Menyusun Rencana Pelaksanaan Pembelajaran (RPP) dengan skenario sesuai dengan aturan main model pembelajaran saintifik model Pembelajaran Inquiri

2. Menyiapkan sumber, bahan, dan semua alat yang digunakan dalam penelitian.

3. Menyusun/membuat lembar observasi guru dan lembar observasi peserta didik.

4. Menyusun alat evaluasi.

\section{Tahap Pelaksanaan (Action)}

\section{Pertemuan I}

1. Guru membagi peserta didik menjadi 7 (tujuh) kelompok kecil, masing-masing kelompok beranggotakan 5 orang peserta didik.

2. Masing-masing kelompok diberikan tugas/soal untuk dipecahkan bersama dalam kelompok, selanjutnya guru berkeliling untuk membimbing kelompok utamanya yang mengalami kesulitan/permasalahan. 


\section{Pertemuan II}

1. Masing-masing kelompok maju kedepan untuk mempresentasikan hasil kerja kelompok secara bergiliran.

2. Tes tertulis

\section{Tahap Observasi (Observation)}

1. Observasi guru :

Dilakukan oleh pembimbing mata pelajaran Pendidikan Agama Hindu observer sekaligus sebagai pembimbing guru dalam melaksanakan Penelitian Tindakan Kelas (PTK).

2. Observasi Peserta Didik :

Dilaksanakan oleh guru mata pelajaran sekaligus sebagai peneliti dalam Penelitian Tindakan Kelas (PTK) pada kegiatan diskusi kelompok..

\section{4). Tahap Refleksi (Reflection)}

1. Renungan hasil perolehan data

2. Pengolahan dan analisa data hasil penelitian

3. Mencocokkan hasil analisa data dengan indikator keberhasilan

4. Rencana perbaikan dan tindak lanjut

\section{SIKLUS II}

Pada siklus ini semua kegiatan dan tahapan selama penelitian adalah sama, sifatnya mengulang dan memperbaiki terhadap tindakan yang masih memerlukan penyempurnaan dan pembenaran sebagaimana mestinya.

\section{Data dan Cara Pengambilannya.}

\section{Sumber Data}

Yang menjadi sumber data dalam penelitian tindakan kelas (PTK) ini adalah semua peserta didik kelas IV Semester Satu tahun pelajaran 2019/2020 di SD Negeri 34 Cakranegara dan peneliti.

\section{Jenis Data}

- Jenis data yang berasal dari guru selaku peneliti

1). Data tentang Rencana Pelaksanaan Pembelajaran (RPP)

2). Data Pelaksanaan Pembelajaran

- Jenis data yang berasal dari peserta didik :

1). Data kemajuan aktivitas belajar

2). Data hasil diskusi kelompok

3). Data hasil belajar

\section{Cara Pengambilan data}

- Data kegiatan pembelajaran diambil dari RPP yang dibuat oleh guru dan lembar observasi pelaksanaan metode pembelajaran model Pembelajaran Inquiri

- Data kemajuan aktivitas belajar; diambil dari lembar observasi selama diskusi kelompok.

- Data kemajuan hasil belajar; diambil dari laporan individu hasil diskusi kelompok dan hasil tes tertulis yang dilaksanakan pada akhir proses pembelajaran

\section{Indikator Keberhasilan dan Teknik analisa} data

Teknik analisa data

Untuk menganalisis data akan dilakukan melalui analisis deskriptif kuantitatif melalui pendataan, analisis dan pembahasan terhadap data yang diperoleh dengan mencocokkan tingkat keoptimalan terhadap capaian indikator keberhasilan yang ada.

\section{Indikator Keberhasilan}

1. guru telah dinyatakan berhasil melaksanakan proses pembelajaran dengan pendekatan saintifik model Pembelajaran Inquiri, bila telah mencapai skor rata-rata $\geq 4,00$ (kategori baik)

2. Aktivitas belajar Pendidikan Agama Hindu peserta didik kelas IV dinyatakan telah meningkat jika $85 \%$ dari jumlah peserta didik telah memperoleh skor rata-rata $\geq 4,0$ dan hasil belajar dinyatakan telah meningkat jika $85 \%$ dari jumlah peserta didik memperoleh nilai ratarata $\geq 75,00$ (sesuai KKM).

\section{LAPORAN HASIL DAN PEMBAHASAN Laporan Hasil DESKRIPSI SIKLUS I}

Tahap Perencanaan

Pada tahapan ini yang telah dilakukan oleh guru selaku peneliti adalah; 1) menyusun RPP dengan skenario pembelajaran model Pembelajaran Inquiri, 2) telah berhasil menyiapkan alat, sumber, bahan yang diperlukan dalam penelitian, 3) berhasil menyusun instrument observasi guru dan 
instrument observasi peserta didik, dan 4) menyusun alat evaluasi.

\section{Tahap Pelaksanaan}

\section{Pertemuan Pertama:}

1. Guru menyampaikan materi pelajaran dengan pendekatan saintifik dengan kegiatan mengamati dan menanya

2. Peserta didik dibagi menjadi 7 kelompok kecil yang anggotanya 5 orang peserta didik secara heterogen

3. Peserta didik berdiskusi dengan model Pembelajaran Inquiri dengan kegiatan pokoknya memecahkan persoalan/soalsoal yang menjadi tanggung jawabnya.

4. Selama peserta didik berdiskusi, guru berkeliling membimbing kelompok sekaligus melakukan observasi/pengamatan terhadap aspekaspek yang telah direncanakan.

\section{Pertemuan kedua}

1. Masing-masing kelompok secara bergiliran mempresentasikan di depan kelas yang diikuti oleh semua anggota kelompok.

2. Guru mengamati/mengobservasi ketrampilan peserta didik selama persentasi sesuai dengan aspek pengamatan ketrampilan yang telah di rencanakan.

\section{Tes tertulis}

\section{Tahap Observasi}

Observasi guru memperoleh skor rata-rata pertemuan I $(3,21)$ dan pertemuan II $(3,36)$, observasi Peserta didik pertemuan I $(3,11)$ dan pertemuan II $(3,40)$. Perolehan hasil belajar dalam bentuk tugas dan tes tertulis pada siklus I pertemuan kedua memperoleh nilai rata-rata sebesar $(67,49)$ dan $(65,71)$.

\section{Tahap Refleksi}

Pada tahapan ini peneliti melakukan kegiatan refleksi sebagai dampak dari perolehan data hasil observasi guru, observasi peserta didik (diskusi kelompok dan presentasi), serta rata-rata nilai tes tertulis sebagai berikut:

1. Renungan data hasil perolehan data pada siklus I

2. Pengolahan data hasil observasi guru, peserta didik dan tes tertulis.

3. Mencocokkan hasil yang ada dengan Indikator keberhasilan.
4. Merencanakan perbaikan terhadap jenis tindakan yang menyebabkan belum tuntas Indikator keberhasilan. Oleh karena Indikator keberhasilan belum terbukti maka penelitian dilanjutkan ke siklus II.

\section{DESKRIPSI SIKLUS II}

\section{Tahap Perencanaan}

Pada tahapan ini jenis kegiatan yang dilakukan masih mengacu pada kegiatan siklus I, bedanya hanya terjadi perbaikan seperlunya yaitu: 1) penyusunan RPP dengan mengacu pada pendekatan saintifik model Pembelajaran Inquiri dan diskusi kelompok dan penyempurnaan pada bagian skenario pembelajaran, 2) menyiapkan alat, sumber, bahan yang diperlukan dalam proses tindakan dikelas senyatanyan, 3) menyiapkan lembar observasi guru dan lembar observasi peserta didik sebagaimana pada siklus I, 4) menyiapkan alat evaluasi sebagaimana yang telah dibuat pada siklus I.

\section{Tahap Pelaksanaan}

Secara umum tahapan pelaksanaan proses pembelajaran pada siklus II ini masih mengacu pada pelaksanaan proses pembelajaran sebelumnya. Pemecahan yang dilakukan pada proses pembelajaran ini adalah: 1) pelaksanaan proses diskusi kelompok kecil lebih dioptimalkan, 2) pelaksanaan pembimbingan kelompok sekaligus observasi peserta didik lebih di efektifkan. Utamanya pengamatan peserta didik yang aktif, yang kurang aktif, peserta didik yang tidak aktif, dengan harapan proses analisa data lebih signifikan, 3) laporan hasil kerja kelompok yang dibuat secara individu yang dipresentasikan dikelas difokuskan, dan 4) pelaksanaan tes tertulis sebagai perwujudan dari peningkatan hasil belajar peserta didik lebih diperketat.

\section{Tahap Observasi}

Observasi guru memperoleh skor ratarata pertemuan I $(4,21)$ dan pertemuan II $(4,43)$, observasi Peserta didik pertemuan I $(4,14)$ dan pertemuan II $(4,63)$. Perolehan hasil belajar dalam bentuk tugas dan tes tertulis pada siklus I pertemuan kedua memperoleh nilai rata-rata sebesar $(77,77)$ dan $(84,00)$. 


\section{Tahap Refleksi}

1. Renungan atas perolehan data hasil observasi guru, observasi peserta didik, dan hasil tes tertulis sebagai wujud dari peningkatan aktivitas dan hasil belajar peserta didik di kelas senyatanya.

2. Pengolahan data hasil observasi guru, observasi peserta didik, presentasi peserta didik dan tes tertulis

3. Mencocokkan perolehan data hasil tindakan dengan Indikator keberhasilan yang telah ditetapkan.

4. Guru memberikan hadiah/reward kepada semua peserta didik kelas IV atas keberhasilannya dalam upaya meningkatkan aktivitas belajar yang berdampak terhadap perolehan hasil belajar sesuai dengan KKM yang telah ditetapkan.

\section{Pembahasan}

Hal-hal penting yang dibahas dari perolehan hasil pada Penelitian Tindakan Kelas (PTK) ini adalah: a) apa yang telah dilakukan, b) apa kendala yang dihadapi, c) faktor penyebab, d) dampak/akibat, e) solusi, dan f) hasil setelah dilakukan solusi/upaya pemecahannya.

\section{SIKLUS I}

\section{Tahap Perencanaan}

Peneliti menyusun RPP dengan skenario penerapan pendekatan Saintifik model Discovery Learning, menyiapkan alat, sumber, bahan yang diperlukan dalam proses pembelajaran, menyiapkan instrument observasi guru maupun instrument observasi peserta didik. Ada kendala yang dihadapi selama persiapan alat dan bahan pembelajaran, tetapi setelah meminta petunjuk kepada pembimbing kendala yang dihadapi pun dapat diatasi dengan baik.

\section{Tahap Pelaksanaan}

a. Mengamati

- Guru menugaskan kepada peserta didik secara berkelompok untuk menggali informasi dari buku paket tentang materi pelajaran yang disajikan.

- Guru menjelaskan materi pelajaran dan memberikan contoh konkrit yang bisa dimengerti oleh peserta didik b. Menanya

- Guru memberikan trik-trik kepada peserta didik tentang tata cara bertanya yang baik dan benar sesuai dengan materi pelajaran yang sedang disajikan.

- Peserta didik secara teratur bertanya tentang hal-hal yang belum dimengerti sesuai materi yang sedang dipelajari.

c. Mencoba (mengumpulkan data/informasi)

- Secara berkelompok peserta didik mendiskusikan masalah yang menjadi tanggung jawabnya.

- Melakukan eksperimen dalam kelompok terhaadap permasalahan yang sedang di diskusikan

- Mengumpulkan data yang berasal dari semua anggota kelompok

d. Mengasosiasikan/mengolah informasi

- Semua anggota kelompok menjawab dan menelaah semua jawaban yang telah di diskusikan bersama

- Hasil jawaban di analisis bersama untuk bisa di paparkan di depan kelas pada saat menyampaikan informasi

- Kelompok membuat kesepakatan akhir dari hasil diskusi kelompok

e. Mengkomunikasikan

1. Guru kembali menyampaikan uraian materi pelajaran terkait dengan hasil kegiatan mengamati, menanya, mencoba, dan mengolah informasi.

2. Guru mempersilahkan kepada semua anggota kelompok untuk menginformaasikan hasil kerja kelompoknya.

3. Semua peserta didik secara berkelompok menanggapi setiap paparan dari kelompok lain

4. Peserta didik dengan bimbingan guru membuat kesimpulan bersama dari seluruh permasalahan/soal yang menjadi tanggung jawabnya.

5. Tes tertulis.

\section{Tahap Observasi}

Observasi Guru

Observasi guru pertemuan I memperoleh skor rata-rata 3,21 dan pertemuan II memperoleh skor rata-rata 3,36, Hasil observasi peserta didik dalam upaya 
peningkatan aktivitas dan hasil belajar Pendidikan Agama Hindu peserta didik kelas IV Semester Satu tahun pelajaran 2019/2020 di SD Negeri 34 Cakranegara diperoleh skor rata-rata pertemuan I $(3,11)$ dan pertemuan II $(3,40)$. Dari hasil tugas dan tes tertulis yang materinya hanya sekitar yang diajarkan pada saat itu juga, diperoleh nilai rata-rata $(67,49)$ dan $(65,71)$.

\section{Tahap Refleksi}

Hasil analisa data peningkatan aktivitas belajar pada siklus I ini $(3,26)$ sedangkan yang diminta dalam Indikator keberhasilan $(\geq$ 4,0), ini artinya belum berhasil. Karena Indikator keberhasilan belum tercapai, penelitian tindakan kelas (PTK) dilanjutkan ke siklus II dengan harapan optimalisasi penerapan strategi pembelajaran dengan pendekatan saintifik model Pembelajaran Inquiri dapat meningkatkan aktivitas belajar Pendidikan Agama Hindu peserta didik kelas IV Semester Satu tahun pelajaran 2019/2020 di SD Negeri 34 Cakranegara.

\section{SIKLUS II}

\section{Tahap Perencanaan}

Peneliti menyusun Rencana Pelaksanaan Pembelajaran (RPP) dengan memperhatikan kesalahan-kesalahan pada siklus I. peneliti lebih memfokuskan tentang Rencana strategi jitu sehingga proses pembelajaran dengan pendekatan Saintifik model Pembelajaran Inquiri dapat terelaisasi dengan baik, karenanya dalam penyusunan skenario benar-benar dirinci dari tiap aspek pada proses pembelajaran dengan model Pembelajaran Inquiri.

Sebelum proses pembelajaran dilaksanakan, peneliti menyiapkan semua alat, bahan, dan segala sesuatunya sehingga dalam pelaksanaan proses pembelajaran berjalan sesuai dengan skenario yang telah direncanakan. Agar proses pembelajaran dapat teratasi maka peneliti juga menyiapkan lembar observasi guru dan lembar observasi peserta didik sebagai tolak ukur ketercapaian peningkatan aktivitas dan hasil belajar Pendidikan Agama Hindu peserta didik kelas IV SD Negeri 34 Cakranegara.

\section{Tahap Pelaksanaan}

Pada tahap pelaksanaan di siklus II ini pada dasarnya masih mengacu pada pelaksanaan siklus I, yaitu penerapan pendekatan Saintifik model Pembelajaran Inquiri dan. Bedanya pada siklus ini lebih dioptimalkan.

\section{Tahap Observasi}

Pada siklus II ini hasil observasi pertemuan pertama skor rata-rata $(4,21)$ dan pertemuan kedua $(4,43)$, Upaya meningkatkan aktivitas belajar Pendidikan Agama Hindu peserta didik kelas IV Semester Satu tahun pelajaran 2019/2020 di SD Negeri 34 Cakranegara pada pertemuan I diperoleh skor rata-rata $(4,14)$ dan pertemuan II $(4,63)$. Dampak nyata dari meningkatnya aktivitas belajar adalah hasil belajar juga meningkat, dari data hasil perolehan nilai rata-rata tugas dan tes tertulis adalah $(77,77)$ dan $(84,00)$ sementara pada siklus sebelumnya hanya $(67,49)$ dan $(65,71)$ berarti mengalami peningkatan yang signifikan.

\section{Tahap Refleksi}

Hasil analisa data peningkatan aktivitas dan hasil belajar peserta didik pada siklus II adalah $(4,39)$ dan $(80,89)$ sedangkan Indikator keberhasilan $(\geq 4,0)$ dan $\geq 75,00$. Ini artinya pada siklus II hasilnya telah melampaui Indikator keberhasilan yang telah di tetapkan.

Karena Indikator keberhasilan telah terbukti, maka tidak perlu ada upaya perbaikan dan penyempurnaan. Pendekatan Saintifik model Pembelajaran Inquiri telah mampu meningkatkan aktivitas dan hasil belajar peserta didik yang ditandai dengan tercapainya Indikator keberhasilan dan terjadinya peningkatan hasil belajar peserta didik. "Penelitian Tindakan Kelas (PTK) dihentikan pada siklus II dengan hasil memuaskan."

\section{Simpulan}

Data komulatif dari hasil penelitian tindakan kelas (PTK) dari siklus I ke Siklus II adalah sebagai berikut:

\begin{tabular}{|c|c|c|c|c|c|c|c|}
\hline \multirow{2}{*}{$\mathrm{N}_{0}$} & \multirow{2}{*}{ Jenis Kegiatan } & \multirow{2}{*}{$\begin{array}{c}\text { Indikator } \\
\text { keberlasilan }\end{array}$} & \multicolumn{2}{|c|}{ Siklus I } & \multicolumn{2}{|c|}{ Sikklus II } & \multirow[t]{2}{*}{ Keterangan } \\
\hline & & & I & II & I & II & \\
\hline 1. & Observasi Guru & $\geq 4,00$ & 3,21 & 3,36 & 4,21 & 4,43 & Meningkat \\
\hline 2. & Observasi Peserta didik & $\geq 4,00$ & 3,11 & 3,40 & 4,14 & 4,63 & Meningkat \\
\hline 3. & Tugas & $\geq 75,00$ & \multicolumn{2}{|c|}{67,49} & \multicolumn{2}{|c|}{77,77} & Meningkat \\
\hline 4. & Tes tertulis & 275,00 & \multicolumn{2}{|c|}{65,71} & \multicolumn{2}{|c|}{84,00} & Meningkat \\
\hline
\end{tabular}

Penerapan pendekatan Saintifik model Pembelajaran Inquiri sangat efektif upaya 
untuk meningkatkan aktivitas dan hasil belajar Pendidikan Agama Hindu peserta didik kelas IV Semester Satu tahun pelajaran 2019/2020 di SD Negeri 34 Cakranegara. Fakta telah menunjukkan perolehan rata-rata skor aktivitas belajar peserta didik pada siklus I ke siklus II sudah melampaui Indikator keberhasilan yang ditetapkan. Penelitian dinyatakan "berhasil" dan dihentikan pada siklus II.

\section{Saran-Saran}

Disarankan kepada guru sejawat untuk melaksanakan Penelitian Tindakan Kelas (PTK) dalam upaya untuk meningkatkan aktivitas dan hasil belajar peserta didik sesuai dengan mata pelajaran masing-masing.

Disarankan kepada para semua peserta didik kelas IV SD Negeri 34 Cakranegara untuk membiasakan belajar dengan pendekatan yang kontekstual utamanya strategi yang mampu membangkitkan aktivitas belajar peserta didik yang dampaknya hasil belajar dapat ditingkatkan seperti yang diharapkan.

\section{DAFTAR PUSTAKA}

Anonim, 2017 , dalam http://dadangjsn.blogspot.com/2014/0 6/pengertiandefinisi-pendekatansaintifik.html, Tanggal 20 September 2017, Pukul 15.32 Wita

Anonim, 2017 , dalam http://desialuthfi11.blogspot.com/2017 107/makalah-model-pembelajaraninkuiri.html, tanggal 20 September 2017, pukul 16.46 Wita.

Arikunto, s. 2009, Penelitian Tindakan Kelas, Jakarta : Bumi Aksara.

Harun Rasyid dan Mansur, 2008, Penilaian Hasil Belajar, Bandung : CV Wacana Prima.

Lukmanul A, 2008, Perencanaan Pembelajaran, Bandung : CV Wacana Prima.

Mukhtar, 2003, Prosedur Penilaian, Jakarta : Rineka Cipta.

Nurhadi, 2003, Yasin ,B dan Sendule.A, 2003, Kontekstual dan Penerapannya dalam KBK, Malang : Unitipetas Negeri Malang.
Robert E Slavin, 2010, Cooperative Learning Teori, riset dan Praktik, Bandung : Nusa Media.

Sardiman, 2007, Indikator Dan Aktivitas belajar Mengajar, Jakarta : Raja Grafindo Perkasa.

Supriono, 2009, Cooperative Learning Teori dan Aplikasi PAIKEM, Yogyakarta : Pustaka Pelajar.

Permen 81A Tahun 2013 Tentang Implementasi Kurikulum 2013 